\title{
DOI: 10.7596/taksad.v5i4.588
}

\section{The Role of Iran and America's Middle East Policy in Peace Process of Middle East 2001-2016}

\author{
Shiva Jalalpoor ${ }^{1 *}$ Hadi Sharfi $^{2}$
}

\begin{abstract}
The Middle East peace process has become the most important international Middle Eastern politics phenomenon during the recent decades. Since the U.S. has realized the political, military and economic power of Iran and its influence as peace building in the Middle East, diplomacy with a common approach on the agenda has developed between these two countries. Therefore, the purpose of this study is to investigate American and Iranian role in the Middle East and diplomatic relations between the two countries in the process of establishing peace in the region. The main question in the present research is that; what is the role of American and Iranian Middle East policy in the peace process in the Middle East during 2001-2016? To response to the question, a descriptive-analytical approach is implemented. The results suggest that the lack of diplomatic relations between Iran and America in the years 2001-2016 is one of the main reasons of the lack of security and peace in the Middle East. Accordingly, creating opportunities and establishing diplomatic relations (political, economic, social, and etc.) between Iran and America with the interests of the two countries as the two poles of influence in all parts of the region, not only provides security, but also is an indicator to stabilize discipline and a lasting peace in the region. Last but not least, communication between Iran and the U.S. ensures safety of the region.
\end{abstract}

Keywords: Diplomatic relations, Iran foreigner policy, U.S.A. foreign policy, Middle East peace.

\footnotetext{
${ }^{1}$ Corresponding Author*, Assistant professor, political sciences, Department of Political Science, Ahvaz Branch, Islamic Azad University, Ahvaz, Iran. E-mail: Shiva_jalalpoor@yahoo.com

${ }^{2} \mathrm{PhD}$ student in international relations, Islamic Azad University, Khoramshahr Branch, Persian Gulf, Ahvaz, Iran.
} 


\section{Introduction}

By Iran revolution incidence, the peaceful relation between Iran and the U.S. terminated and new era of political communications started between two countries, according to the Iran and the U.S. special relation after Islamic revolution, one of the most challenging issues for both countries was diplomatic relation cut off in regional and international level. Both countries' relation began since the middle $19^{\text {th }}$ century and until August1953, the U.S. was considered as the third power by Iran for coping with pressure of two other poles which were Russia and England. In this period there was relation between both countries but after the coup August 1953 (as known 28 Mordad coup), we observe the new era of relations and correspondences between both countries. In this era, the process of American relation was obvious in Iran, actually since then the cooperation between both countries expanded in all aspects of policy, economy and military. By Islamic revolution event in Iran, the U.S. was one of the countries that realized the Islamic revolution legal but by victory of Islamic revolution the regional equations were disordered and the U.S. lost its main united party in the region and the relation between both countries changed to tension and therefore the field made for both countries communication cut off.

Different factors are presented from both countries to determine the conflict in Iran and the U.S. relations. The U.S. has declared the most important factor as the Iran disagreement with the Middle East peace process and Iran support of terrorism and attempt to achieve the nuclear weapon and also expansion of rebel radical movement all around the Islamic countries. The U.S. has claimed that its benefits are in danger in Middle East due to Islamic republic of Iran and in reverse Islamic republic of Iran believes that the U.S. manipulated reason for standing against Iran is; Iran objection about the U.S. doctrine and Iran disagreement with the U.S. Middle East policies specially in Persian Gulf presence and development of Islamic ideology and support of Muslims freedom movement are the cause of this conflict.

After the Islamic revolution victory in Iran and financial, spiritual and material support of revolution from Palestine freedom movement and increase of dispute between Arabs and also Palestine groups conflict with Israel and also the U.S. definite support of Israel regime, the Middle East frequently faced with different upheavals. In one hand Iran believes that the region issues should be solved by the local people and the powers out of region should not present in the region. However, the U.S. and other trans-regional powers increase their presence to support Israel and their acceptable regimes and monarchs and in other ideas from 
analysts at the present time the U.S. in one hand and Iran on other hand are fulfilling their policies in the region and till now these two counties do not achieve agreement together about some principals, it does not seem that the stable peace is established in Middle East region (Laqhaie Tabar 2001: 1-8).

But first to realize the new upheavals deeply, the present article tries to present the philosophical realization and classic understanding about the peace concept as well as the Iran and the U.S. diplomatic role in region will be evaluated. The main question in the present research is that; what was the role of Iran and the U.S. Middle East policy during 2001-2016 in Middle East peace process? So the present research purpose is to criticize and evaluate the Iran and the U.S. political and philosophical role in Middle East region and the diplomatic relation of both countries in making peace in Middle East. In this study it is assumed that lack of diplomatic relation between Iran and the U.S. during 2001-2016 is the main reason of insecurity and lack of peace in Middle East region.

\section{Conceptual framing}

\subsection{Middle East}

Middle East is the region that includes the land between the Mediterranean and Persian Gulf. Middle East is the part of Africa and Eurasia or specially it is considered as Asia and in some subjects it includes the North African. Many of Middle East description either in the source encyclopedias or in the public explanation are the part of Asia western south and including countries between Iran and Egypt. Although most of Egypt land except the Sina desert is located in North Africa, it is assumed at the Middle East land, African north countries as Libya, Tunisia and Morocco in contrast to Middle East are named as the North African countries in public and the media.

Middle East is the term that was attributed by European to this region according to the geographical condition of their own land while this region is approximately is located in the middle lands of earth. For this reason, some people criticize the Middle East term due to the European tendency in this terminology. The Middle East expression became prevalent when some parts of England and French people used it and other countries around the world without and definite reason copied the Middle East expression directly from French and England.

Due to having great sources of oil, Middle East has significant importance. Iran, Saudi Arabia, Kuwait, and United Emirate are countries that have the largest oil resources in the 
world. Middle East also has the greatest gas sources and Iran and Qatar are orderly the first and second gas owner resources in the world. The oil land economies in Middle East mostly is the single product economy and it is depended to the oil and the oil resources are used fewer in the industrial section, Yemen is one of the poor countries in the region. All Middle East oil producing countries are categorized in MENA (Middle East and North Africa) countries group.

The Middle East concept although pointed out to a special geographical condition, up to present time due to presence of effective forces lacks of a common security identity and organized figure. In the natural condition sub-structure regional system should shape in a historical process and following to it a national units common need is formed so the attempt to define a region from external powers is equal to its forming powers purposes before being adapted to the region needs and requirements (Vaezie 2005: 39).

\subsection{Peace}

Peace is the condition in which there is no war (Langerudy 2005: 408). Peace had the same meaning in international relations before the establishment of the United Nations (Bigzadeh 2010: 516). But the United Nations extended its meaning and regarded as the international order based on justice (Ibid). Accordingly, only lack of war does not mean the peace maintenance and continuity.

Rather, every action that is in contrast to justice might lead to threat of peace and its defection. This view strengthened by the end of cold war, the Security Council leaders in an announcement in January 1992 declared that today lack of war and disagreement between governments does not mean the presence of peace and security in international level. Lack of stability in social, economic and political fields and break of human right is considered as the threat for the global peace and security (Declaration of the President of the Security Council). The article 2 and 3 of law no. 10 from the United Nations charter declares the strengthening peace through developing friendly relation in international level that leads to reduction of war events reasons and solidification of peace, but today by the end of cold war peace is not regarded as the military contact rather poverty, hunger, democracy, prejudice and inefficient government, human rights breach are threats for the international security and peace. In this view even the governor's interference is not only illegal, rather it provides the basis for the international peace and security (Ashrafi 2014: 84-107). 


\section{Middle East policy of Iran}

Islamic Republic of Iran's national benefits are similar to other countries as made of two material and spiritual elements. In this formula, Islamic ideology not only is one of the Iran national benefits rather it is part of its national benefits, as the Iran national identity that is made of Iranian, Islamic, third world and international elements. As the results, the difference and separation between national benefits and Islamic targets is not precise because this categorization needs definition and determination of Iran national identity based on two Iranian and Islamic elements. While these two elements has shaped the united element in Iran national identity structure that are inseparable and as it is not possible to separate Iranian and Islamic identity of Iran nationality, it is not possible to separate the national benefits and Islamic profits too and as the result there should be attempt to direct the national benefits by making balance and coordination in ideology and pragmatism and Iran foreign rationality (Erdam 2014: 77; see Y1lmaz 2013: 16-34 and 2014: 4 for other examples of Muslim countries in this mixture of Islamic and national identities).

According to the plan and foreign policy construction, basically the principals follow the system that is the outcome of power and national target and environmental condition. Fixed assumptions exist in categorization of foreign policy strategies that mainly are related to the behavioral structure and culture in a government. The foreign policy in Islamic Republic of Iran main law is ideology view and issues as objection of dominance and world Muslims right support and human welfare in all human society and right and justice government to whole world and support of poor toward tyrants in all around the world are the main targets of Iran foreign policy in Iran law.

The view and revolutionary behavior is one of the main features in Iran foreign policy after revolution. The revolution institutions role in foreign policy operations environment is more colorful that governmental system and diplomatic system due to ideology purpose to object the dominance and defend of suppressed and freedom powers in all around the world according to the item 16 of article 3 and principal no.154 of main law (Iran realize the human welfare in all human society and assume the dependency and freedom and the right and justice as every people right, so as it avoids any interference in other nations internal affairs, it supports other suppressed people toward tyrants in every points of world), the foreign political view basically is against the present condition and in conflict with dominant system to the global orders and regional arrangement. Maintaining definite limit of distance and 
standing toward the U.S. as the symbol of global arrogance is one of the Iran foreign political permanent trainings.

The Islamic republic of Iran foreign policy also has its specially order and organization, the national benefits and targets are not permanent but they have stable role in foreign policy and structure and naturally the nation main elements are the vital benefits of every political regime. About Islamic republic or Iran the land, regime protection and people and belief boundaries and ideology are at the top of national benefits and foreign policy is ordered to protect these national benefits and usually the material needs to fulfill these targets and providing ideology benefits is more that the ideological countries national power. Iran is a country that has national considerations (only on the territory of Iran) and international considerations (mainly related to the Muslim world). In other words, here the state-nation logic as well as religion, or ideology logic is important. Many upheavals in the international level and in corresponding environments and also various threats especially asymmetric threats require a kind of strategy that is combination of ideology, pragmatism and rationality and three principals of esteem, wisdom and interest are put at its frontier model.

Understanding the Iran foreign policy is the accurate and complex issue, in one hand evaluation of this country foreign policy could be done by assistance of social theory in general use and international relational and foreign policies in specific meaning, on the other hand due to special features of Islamic Republic of Iran. There should be care to pay attention to understanding its behavior, so we should remind that Iran foreign policy because of Iran development, foreign policy national principals and its coincidence with foreign political Islamic rules and its relation with international relations theories have more signification (Erdam 2014: 76).

Parallel to international role and making active neutral policy toward international powers, Islamic Republic of Iran in regional level has paid attention to power three aspects balance in facing to the geopolitics of Shia by Iran leadership and Salafi by Saudi Arabia leadership and Ihvany by Turkish leadership to avoid power disorder in Middle East.

Iran has managed to concentrate its activities in several fields, first confirmation on regional democracy as the model adapted to the norms and values of region and second by attempt to develop political, economic and security cooperation with regional countries in order to reduce the rate of foreigner powers' interference in the process of regional order maintenance. The economic structures correction and response to the young population increasing demands and their job inquires through assistance to markets and making regional economic institutions are the main important fields of expanding regional cooperation (Vaezi 1984: 
118). Third avoidance of any coalition between Turkey and Saudi Arabia and fourth attempt to find political solution for Syria crisis and prevention of longevity of this conflict and also avoidance of its expansion to military and cultural fields (Yazdan Panah and Janfeshan 2013: 284-257.

Islamic republic or Iran policies consider positive and negative views according to strategic proceedings in Middle East region in the same time.

- Facing with isolating and limiting Iran through increase of cooperation and active participation in all systems and regional organizations by the use of bilateral and multiple diplomacy.

- Regional institutionalization through making organization and regional multiple system and methods by cooperation and effect on other region players' foreign policies and through application of two and multiple active diplomacy is some activities in this field.

- Avoidance from assuming Iran as the security issue through making confidence and clarification in foreign policy and application of active and multiple diplomacy in organizations and regional strategies.

- Development regional legitimation of Iran through normalization and increase of bargaining power in organizations multiple strategies.

- Avoiding disputes and regional crisis through supervision on regional upheavals by the use of presence in organizations and regional multiple techniques.

- Making confidence through increase of reliance in regional countries about organizations and regional multiple strategies in cooperation to apply clear and real diplomacy.

- Wide cooperation and membership of all organizations and multiple strategies in region through making thrust and constructive correspondence with region countries by the use of geopolitical, geo-cultural and geo-economics conditions (Akrami, 2013: 56-57).

A fast evaluation in Iran policy during past four decades reveals presence of two main views in the national and organizational level.

A. The expanding view (security-based approach)

This based on Iran law according to the revolution issue and the global mission to fight with tyranny and dominance and the ideological view which prescribes and strengthens the security center principal. This view assumes the regime protection following to the religion boundaries as the criterion for the foreign policy and considers this factor as the center of opportunities and threats definition which are related to the revolution and country.

The security and revolutionary view assume Iran security environment up to the ideological targets boundary. This view considers the spiritual and material power at the top of national 
priorities to expand the parallel power in facing with arrogant powers dominance in the regime security environment. In other word this view is the security-centered issue, the protection of parallel making power in security penetration field is the essence of this view.

B. The growth centered view (the international system-based approach)

Other view is the classic and ordered view about the foreign policy. In this view in the national institutions, foreign policy is greatly realistic and growth centered but in international environment it is idealist and at the same time with structuralism view.

This view recognizes the international system at the actual issue and as what it is. It beliefs about total cooperation to the combination level with international system in political, economic and even security. The main law ideals, benefits and ideological benefits and even national dependency are considered in this view a little.

This view believes the action originality in high extend to develop the political relations. The central factor in continuity of a country is observed in national development scales and it assumed the national development scale fulfillment in the foreign policy by combination of regional and global relations on the basis of cooperation benefits in international activity distribution, so it has tendency to the liberalism in the international relation environment. In one sentence this view is the development centered and combination with international system is the essence of this view.

Because Islamic Republic of Iran similar to other governors is not in the condition to be able to follow all ideals, including both spiritual and material, at once to following targets, so categorization and ordering national purposes was needed to arrange the foreign policy. In the present time at 2016 also the joint comprehensive plan for action has provided new condition for Iran and it includes of opportunities and several threats. Three aspects of this agreement include the technical, tactical and strategic level that each of them has effects and outcomes to Iran strategic environment.

Two different targets including the national development reconstruction path and keeping the security priority in agitated environment are at the Iran foreign policies priorities, it is the unhidden reality that the mentioned conditions needs special and separate strategies but we cannot evade combination necessity in these two views, the solution is to make combined strategy and multiple technique, based on this reality the country should take a serious action, a combination of both techniques in foreign policy ( expanding and growth centered) in a combination solution package. Powerful countries axis including the west or east or the neighbors including friends or enemies have their own defined and determined situation. 
The west-east positive balancing solution as the main basis for the foreign policy has been taken into consideration; also the mutual dependency in regional correspondence is the format for the country regional policy. In this combined solution, Islamic republic of Iran in macro level keeps the cooperation and positive relation open between the powers from overseas and also plays the active and determinative role in the region in addition to keep the balance in power factors maintenance.

The war continuity and its expansion could endanger the trans-regional powers benefits; also the same factor provides the proper opportunities for Iran in the middle of global and regional policies.

The Iran security balancing power is the warranty to protect the condition and play an active role in providing the vital and necessity benefits of country in these critical events. At the same time, the power and security pyramid is kept at the level below the country surrounding security systems to direct the crisis in the management and control path (Akbary 2015).

Iran view about the surrounding environment is based on the security model which is according to the cooperation, in this view the serious cooperation with all regional countries is put in to priority to organize the regional security structure and effective cooperation in this field. On the other hand, the continuous presence of trans-regional powers is objected in the regional security orders and this presence is the main factor in increase of disputes and tension in the regional level.

Iran security view according to the recent years' experience in region has criterions and elements that if paid attention could be led to stable secure regime formation. The first criterion in this view is to reduce the regional military powers that cause exceeded tension and terrorism and destruction of cooperation in region countries natural relation, the second criterion is cooperation of regional players in security structure specially in cooperation of greater countries as Iran, Turkey and Saudi Arabia in solving challenges as terrorism and religious-tribe groups correspondence with national units. According to the challenges and security disputes expansion in Middle East and different factors effect in sub-nation, national and regional level in making insecurity and instability in region, making security in the security model format based on cooperation requires long term and gradual process. In this process the regional cooperation not only is fulfilled by building trust step by step and making mutual confidence between countries and also through attempt in solving challenges, rather it is the product of some structural discrepancies as the government-nationalization problem and culture weakness and democratic processes. 
Iran tries to solve the security challenges with cooperation and participation of regional players based on the mentioned view in every field of surrounding environment.

\section{Middle East policy of the U.S.A.}

According to the dominant theories in U.S.A. foreign policies and its description we can say that Middle East with its specifications is actually the key to control the world and safe America (Cultural Department of the Joint Staff Corps 1989: 19). We can count some main features that describe the Middle East station of American neoconservatives' strategy, including:

4.1.1. Changing the power identity from the American strategists' point of view due to economical axis in international policy, could control dominance of players which are rival with the U.S. on Middle East (Naserpor 2006: 18).

4.1.2. Middle East is the center of political Islam and asymmetric threats for the U.S., the growth is Islamic view have three important outcomes for American if there is no control on it: a) U.S.A. allied governors in region will collapse; b) Israel regime is put into danger; and c) U.S.A. era will be terminated in the region

4.1.3. In American governors' point of view, Middle East oil is the energy supplier for whole world, based on a research the U.S. dependence to oil in three pass decades is equal to 4 to 15 trillion dollars (American National Security Strategy Edition Commission 2011: 179).

So we can say that Middle East is the key for stability in the world and the main challenge in this path based on the U.S. view and its considerations, so the U.S. follows three strategic targets in region at the same times which are: 1) Geopolitical purpose; that means the U.S.A. dominance on the region geopolitics as leads to facilitation of global dominance order; 2) Economical purpose; as the U.S. access and control is limited to the regional energy; and 3) It takes the global doctrine and administration.

The plan of great Middle East was implemented according to three strategic purposes: 1) Nation building by the mean of changing the population context and cultural model; 2) Building country by the mean of changing regional geographic plan; and 3) Building government by the means of governors according to the U.S. democratic liberal model. Actually by focus of the White House governors' analysis method it is clarified that they assumed the root of September $11^{\text {th }}$ event in the Middle East and they regarded the democracy expansion in this region as the antidote to cope with terrorism (Corrdenz 2003: 403). 
In other words, the U.S. foreign policy in this period found two main features that from one direction it is regarded as the democracy prevalence and following the targets to achieve strategic triple targets and form other hand fighting with terrorists is regarded as the challenging force that is assumed obstacle for the American strategic targets. This ideology of America that was put in to agenda after September $11^{\text {th }}$ specifically has four main scales in Iran relation.

\subsubsection{U.S.A. conflict with Iran based on the just war theory;}

Based on the democratic peace theory, it is necessary that the domination power cope with the challenging and radical countries.

\subsubsection{The conflict ideology in the contrast format with radicalism;}

The Islamic structuralism that is supported by Iran is interpreted as one of the factors and signs of security threats in U.S.A. According to Farid Zakaria, Iran radicalism has root in political process (west criticism) since 1950 but the peak point returns to the Iran revolution period (Farid Zakaria in 1965: 170) of course American believed the strategic discrepancy with Iran and they believed that only realizations and democratic norms with American definition could reduce conflict (Motaqhi 2006: 109) but frequently they were worried about the Iran reaction processes.

\subsubsection{Advertising and political preventive proceedings;}

The best document to present this scale is the U.S.A. National Security Strategy document in 2006 in which the fight with Iran has been mentioned inside of a publicized official document. The document carries the seal of the President of the U.S. and signed by the thenPresident George W. Bush. The document manifests;

We may face no greater challenge from a single country than from Iran. For almost 20 years, the Iranian regime hid many of its key nuclear efforts from the international community. Yet the regime continues to claim that it does not seek to develop nuclear weapons. The Iranian regime's true intentions are clearly revealed by the regime's refusal to negotiate in good faith; its refusal to come into compliance with its international obligations by providing the IAEA access to nuclear sites and resolving troubling questions; and the aggressive statements of its President calling for Israel to "be wiped off the face of the earth." The United States has joined with our EU partners and Russia to pressure Iran to meet its international obligations and provide objective guarantees that its nuclear program is only for peaceful purposes. This diplomatic effort must succeed if confrontation is to be avoided (The National Security Strategy of the United States of America, 2006). 
4.2.3. The political dispute with Iran by the U.S.A. accusation of war with terrorism;

After the USSR collapse, the American ideology on the basis of coping with groups and Islamic forces formed and based o this view, Afghanistan, Iraq, Iran, Syria, Sudan, Libya and other groups as Lebanon Hezbollah, Islamic Jihad, Muslim Brotherhood, Al-Qaeda were attributed in the terrorist behavior atmosphere. In this direction, the type of behavior from each of countries are different with each other, Libya kept its political existence by cooperation with the U.S. Al-Qaeda has started fighting with the U.S.A. with its special ideology. Islamic Jihad and Hamas in Palestine try to keep their identity through political and military strategies. Taliban was omitted during the Afghanistan war and Saddam also was taken away during the attack to Iraq. Sudan is under pressure because of Darfur file by the United Nations and many attempts are made to omit Syria from Lebanon scene and come to negotiation with Israel and beside it, the U.S. tries to omit Lebanon Hezbollah that was not successful up to now. In this social and political enviorenment, Iran situation should be analyzed in other way. Americans believe that any power production in a country as Iran leads to increase of terrorism, so it is attempted that Iran social and structural capabilities and Iran strategy are reduced parallel to each other (Motaqhi 2006). Proceedings as the economical sanctions, political pressures, threats and attempt to prevent the technological breakthroughs especially the nuclear science and other actions which are taken in consideration to avoid Iran power are in American government agenda. If the U.S. could remove all these challenges to maintain peace in Middle East and provide effective limitation on Iran, to determine Iran situation in the Middle East puzzle as it wishes, we might say that we have achieved three strategic purposes that were issued before. But at the present time we can claim that the U.S. intention for establishing its doctrine in region is defeated and the power to cope with it that means Iran has changed to the regional power and the important issue is that the Iran regional power is due to the U.S. unilateralism and this subject has become clarified in four main open profiles analysis in region.

it is necessary to point out two criterions in the U.S. foreign policy that means the fight with terrorism and democracy prevalence that are in discrepancy with each other, so if the U.S. wanted to concentrate to the building of countries and nations in the Middle East, one of the requirements was to open the political space in the region, in this condition the Islamic groups had potentiality for dominance and growth and the sample is Muslim Brotherhood in Egypt to take high vote in parliament election or Hamas empowerment during its election that formed the government and it does not have coordination with the U.S. policy criterions. On the other hand, if the U.S. wanted to support other powerful regimes as Egypt, Jordan, Saudi 
Arabia or other Arabic countries and asked them to stop Islamic groups (which are terrorist according to the U.S. definition) in this way the claiming democracy does not have meaning. Many of western critics believe that Islamic groups have more attraction in a political dispute compared to secular and western parties supports but their plans is not equal to democracy definition in west (Winderson 2005: 117-121).

According to the Frank Wincer statement who was the U.S. past ambassador in Iran project panel, he mentioned the question that what is the dealing which allow Iran to accept the U.S. legitimation in region and gives opportunity to the U.S. to legitimate the Iran situation? And to the time we don't have the understanding package with Iran, we can neither go to Geneva for Syria conference, nor we could have warranty for ships and American sailors in Persian Gulf, nor we might plan and present any management framework for Afghanistan to be able to be respondent to Israel sensitivities in region.

There were other views in some political complex and the U.S.A. strategies that believed security in Middle East obtained in conditions that dealing with countries as Iran is changed and cooperation diplomacy should be replaced to other models. The Hamilton-backer committee about Iraq is the sample of such view that believes there should be cooperation with Iran and Syria about Iraq.

With some contemplation of this statement we realize that U.S.A. has understood Iran plays a main role in all Middle East events as the power and asks for the peace and stability in region. Hence, the U.S. new diplomacy has been written following to understanding with Iran because common diplomacy in both countries is provided by mutual peaceful relation and since the President Hassan Rouhani's victory in the presidential elections and his attribution as Iran president, main and constructive negotiations has been done about Iran nuclear program that led to the join comprehensive action plan in 2014 and provided the mutual agreement to achieve this comprehensive common plan in April 2015.

If Iran nuclear program is solved, surely the field of cooperation between Iran and America will be provided. Both countries have common benefits in the region and fight against drug smuggling and endeavor to provide stability in Iraq and Afghanistan, control and destruct ISIS terrorism. In addition, both countries intend to terminate the Syrian civil war and provide the security and stable peace in the Middle East. Therefore, the general solution based on the mutual respects regarding Iran nuclear program could be the effective step in more cooperation between Iran and the U.S. to change the paradigm in paving the path in relations. 


\section{The role of Iran and the U.S. diplomatic encounter in the Middle East on the peace process}

Generally, two views are present about Persian Gulf, the internal made and external made security views. According to the external view, elements and criterions are outside of region define security in Persian Gulf, so the outward security in Persian Gulf is due to requirements and consideration of countries security out of this geographical limit. In the case of the internal view, security in Persian Gulf is due to needs and considerations and security equation between countries in this region. The challenge between Iran and the U.S. continues for about 33 years. This conflict is one of the longest disputes in the global level and it reminds the cold war between the USSR and the U.S.A. that prolonged for more than 40 years. Iran and U.S.A. were countries that in past three decades tried to make peace in Persian Gulf based on the security structures and solutions. Iran tries to find internal made security without attention to the undeniable effect of the U.S.; on the other hand, the U.S. mainly follows the external-based security without attention to the role and outstanding situation of Iran in Persian Gulf security.

So regardless of any understanding from member countries, the cooperation in a format will provide a security order more than their demand and intention that is the result of a necessity and common request. Based on this reality, the countries in this region are in the security system that is jointed together in which they are affected from the mutual security dependency. In that case, all members are present through cooperation, using security system together provides this opportunity for all regional countries (McMillan 2003: 161-163).

Based on the model of (cooperation and also multiple security responsibility) the regional as more effective role players have in Persian Gulf security structure in every degree, the present instabilities will reduce more and the field to make stability will be provided in the region (Motaqhi 2006).

The confirmation in using this system more than anything also shows that the security arrangement inefficiency is because of past event, in past regime two deficiencies existed, first as the Persian Gulf council in which most of them were against Iran or similar to the U.S. security strategies in the regional level, they had the hegemonic feature (Kraing 2004: 145147).

These two discrepancies accompanied with issue of two countries of Iran and Iraq neglecting in regional decision making are considered as the deficiency factors in security providing system in Persian Gulf. 
The U.S. security strategy is always based on ignoring opinions of Iran and Iraq regarding regional arrangements, while as it was mentioned in a regional complex and in a security system, only it is possible to provide security by all member cooperation, even the countries which are member in Persian Gulf cooperation council regard Iran as the best option for America to be negotiated with. They also ask Washington to pay attention Iran security concerns and do not prevent Iran strategic, economic and political cooperation with regional countries (Yafeh 2007: 21).

In events and continuous complains in Middle East countries as Tunisia, Egypt, Yemen, Bahrain and etc., we see the conflict of American and west sided soft power and talking with Islamic and revolutionary soft power and statement. To the point, that Arabic and Muslim nations assume Iran as one of their model for Islamic tendency. Muslim Brotherhood in Egypt, Ennahda Party and Rached al-Ghannouchi in Tunisia, Shia in Bahrain and Iraq, Hamas groups and Islamic Jihad in Palestine Lebanon Hezbollah and Syria and other Islamic movements that today are considered and the powerful player between nations and government thoughts have received affection from Islamic revolution movement, of course discussion is not about the effectiveness degree rather the principal is the effectiveness reality that is undeniable and Iran could be out of western and American discussion and carries new and exclusive political and cultural and religion values in region (Mohammadi 2008: 4).

Because Iran and the U.S. relation after Islamic republic of Iran establishment has faced with challenge and disputes, political and diplomatic relation cut off between two countries also have increased these discrepancies. Both countries have their tools and capacities in exhibiting their capability and soft power against each other in a struggle. It could not be ignored that regardless of the U.S. hard and soft power against others, Islamic republic of Iran soft power at the present time is one of the challenging and serious obstacles in expansion of the U.S.A. hegemonic policy in the Middle East and even the world (Shakeri 2014).

So with new upheavals that make balance in future of the Middle East policy and power requires a degree of simultaneous presence of foreigner powers and regional powers, the matter that is defined as the mutual equipment. In other word in addition to foreign powers, the need to regional powers and their role to keep their benefits, regional powers also need trans-regional powers for finding opportunities and establishment of their dominance basis. This dedication is based on this logic that the use of power basis in national level is not the criterion for validity and providing opportunity for that country in the political field in international level. In other words, use of national treasure and power of countries provides the basis to achieve proper portion of roles only up to specific level. Other aspect of 
rulemaking is depended to the degree for dominance out of national boundaries, so in some degree of mutual cooperation, it is necessary to distribute roles between the players in the win-win play format. Actually the main players' role in this process is cooperation toward demand and present intention and making stability and security, so that in the shadows of cooperation roles and opportunities fields have found capability for emergence and through that way it will lead to tangible benefits for all players in the security.

Therefore, it seems that Iran and the U.S.A. are two regional and trans-regional powers that the Persian Gulf future has direct relation to their power equation. If we might accept the security combination in Persian gulf is passing its era at the present time, we should say that the most important challenge in Persian gulf security is depended to the Iran-U.S.A. conflict and solving this dispute will identify the future of Persian Gulf, that means the future security structure of Persian gulf is the function of Iran and the U.S.A. relation and in other word the destiny of Persian gulf is on the hand of U.S.A. and Iran as the most important and influential player in Persian gulf security arrangement.

\section{Conclusion}

In this article, foreign policies of Iran and the U.S.A. regarding the Middle East were discussed and different solutions about the Middle East were evaluated. The study concludes that after years of sanction and lack of Iran diplomatic relation with the U.S.A., which assumed itself as the thorough power and tried to isolate Iran in region, Iran has managed to produce foreign positive policies through making diplomatic relations with other region countries.

On the other hand, Islamic Republic of Iran's leadership strategy and Iran's diplomatic behavior flexibility in region presented the warrior flexibility policy parallel to the U.S.A. unclear conspiracy and soft correspondence against Iran, and regard it as the victory in Iran historical policy. This strategy not only nullified western worries about Middle East exchange resources achievement, rather it led to reduction of western interference in region and forced the U.S.A. to come for negotiations in the field for common benefits. This issue led to take influential steps in region problem solving and making peace and security.

Therefore, we can understand that the combined strategy is the regional upheavals solution. This solution is on the basis of process realization and internal and external players in region that are mainly to shape the Persian Gulf security structures. In this strategy, the main and influential players are Iran and the U.S.A. and the relation between two countries is going to be active that identifies the Persian Gulf security model formation and structure. In other 
words, the most important security concern in Persian Gulf that is increasing of Iran dominance in Iraq and following to it in Persian Gulf region, also Iran nuclear program and regional balance disorder for Iran benefit and the possibility of Iran reaction to the U.S. or Israel mighty attach to Iran in Persian Gulf is entangled with Iran and the U.S. relations. Actually the Persian Gulf security structure is the function of Iran and the U.S. relations as the greatest and most influential present players in Persian Gulf security relations. So it is clear that increasing the diplomatic relations (social, economic, and political) between Iran and the U.S., as two influential poles in the region, not only provides security, but also it is the scale for order stabilization and finally the stable peace in region.

\section{References}

Akbari, A. (2015). Foreign Policy of Iran after JCPOA. Iran Analytic News Agency.

Akraminia, M. (2013). Goals of the US from Imposing Sanctions Against Iran. Basaer Political-Strategic Journal. pp. 56-57.

American National Security Strategy Edition Commission. (2011). US National Security Strategy in Century. Translated by J. Dehmashgi. Tehran.

Ashrafi, D. (2014). New Interpretation of Peace and International Security and Its Effect on the Concept of National Governance. General Law Research Journal. No. 42; pp. 84-107.

Barzgar, K. (2006). New Iran-Iraq and Regional Security System of Persian Gulf. Strategy journal.

Beigzadeh, I. (2010). Law of International Organizations. Majd Publication.

Cultural Department of the Corps Joint Staff (1989) End of America in the Middle East. Tehran: Sepah Publications.

Coopani Rostami, M. (2010). Role of IRI in Security of Middle East. Siasat Rooz Journal.

Cultural Deputy of Guard Joint Staff, (1989). Ending the Era of US in the Middle East. Tehran. Sepah Publication.

Erdam, N. (2014). Strategic Components in Formulating Foreign Policy of Islamic Republic of Iran. Iran Diplomacy Journal, pp.76-77.

Jaffari Langarodi, M. J. (2005). Terminology of Law. 15 ${ }^{\text {th }}$ Edition. Ganj-e-Danesh Publication.

Laghaeetabar, M. (2011). Outlook of Middle East Peace by Emphasis on the Relations of Iran and the US. M.A. Thesis. International Relations Faculty. Geelan University. 
Mohammadi, M. (2008). Sources of Soft Power. Social Capital of IRI. No. 16.

Motaqhi, I. (2006). America, Fragile and Strategic Hegemony of IRI. Tehran: Research Center.

Naserpour, H. (2006). Militarization of the US Foreign Policy. Strategic Information Journal.

Regional Stabilization and Security Society in Persian Gulf. Diplomatic Hamshahri Journal. Translated by Motagghi I.

Shakeri Khoee, I. (2014). Cultural Encounter and Soft Power in the Iran and US Relations. Islamic Revolution Studies Journal. 32.

The National Security Strategy of the United States of America (2006). Washington, D.C.: The White House.

Vaezi, M. (2005). Islamic Republic of Iran and the Great Middle East Plan. Strategy Journal. No. 39.

Yafeh, Judis. (2007). Security Strategies of Persian Gulf. Translated by S. M. Azizi. Research Report. Tehran: Strategic Studies Faculty.

Yazdanpanah, M. Janfeshan, M. (2013). Changing Military-Security Strategy of the US from the Middle East to Pacific and Its Consequences for IRI. Winter, 2013. No. 85, pp. 257-284.

Y1lmaz, Selman (2013). State, Politics, and Religion: Effects of Political and Social Change on the Relationship Between State and Religion in Turkey, 2002-2014 (Dissertation). Pittsburgh: University of Pittsburgh.

Y1lmaz, Selman (2014). Cultural Muslims: Background Forces and Factors Influencing Everyday Religiosity of Muslim People. Journal of History Culture and Art Research. 3: 3, pp. 1-19.

Zakaria, F. (1965). Future of Freedom, Priori of Liberalism. Translated by A. H. Nourozi. Tehran. 